\title{
Towards Contextual Prophetic Preaching
}

Filip Grujić

Baptistička crkva, Zagreb

filip.grujic88@gmail.com

UDK: 2:287;2-475;2-766

Original scientific paper https://doi.org/10.32862/k.14.1.4

\section{Summary}

This text is a discussion about prophetic preaching as defined in the boundaries of homiletics. It offers both a theological and practical presentation of this preaching style actively seeking a way to contextualize it in Croatian setting. It offers some answers to the question: What is prophetic preaching and how and why it is done? It also serves as a challenge and the beginning of the discussion on prophetic preaching in Croatian context. As the Church in a growing post-Christian setting seeks ways to communicate the Gospel with the wider society aware that it is slowly losing its privileged footing it seems important to find again the prophetic voice which calls people and institutions of power to get right with God and see human beings as neighbors and not means.

Key words: Prophetic preaching, Homiletics, Social justice, Powers and Principalities, Church, Mission, Righteousness

\section{Introduction}

A lot has been said and written on the topic of prophetic preaching and this article seeks to add the contextual touch to this important homiletical topic. As a homiletical style prophetic preaching is still a fairly undiscovered theme in the Croatian context and not much has been written. This article seeks to introduce and present prophetic preaching in its definition and practice to propose a possible path and need for further exploration of this important homiletical style. In a time when the Church is actively seeking new ways to meaningfully communica- 
te with society and maintain its God-given mission, prophetic preaching presents a challenge to the Church in general, but also specifically to the Church in Croatia which is often seen as alienated to the reality of the actual needs and sufferings of the people. In this article I will try to approach the topic of prophetic preaching as examined by different scholars and employed by different preachers.

As the word "prophetic" can be ambiguous in meaning, I will first seek to define prophetic preaching in the context of this article. I will give an overview of the main features of prophetic preaching and how it fits in the wider homiletical project. I will give two examples of prophetic sermons in their respective contexts and analyse how the prophetic message is conveyed along with mentioning the different biblical and theological images used. In the end I will proceed to map a possible path for prophetic preaching in the Croatian context and identifying the "principalities and powers" 1 that prophetic preaching would require to identify and challenge in the Croatian context.

\section{Definitions}

\section{Prophetic}

In today's time and age, the word "prophetic" is used in many ways and the New Testament itself gives account of the gift of prophesying as one of the gifts of the Holy Spirit. Such a manifestation can bring about prophetic messages aimed at individuals or groups that serve the purpose of encouragement, challenges, and sometimes a vision for the future. This type of practice is present and encouraged in numerous communities of faith. However, the focus of this article will be to explore prophetic preaching as a term closer to the message of the Old Testament prophets whose practice among others ${ }^{2}$ was to identify the socio-political situation of the people of Israel, and publicly challenge, confront, hold accountable, and call into responsibility the institutions of power or spiritual and religious deviances that were the agents of the social injustice of the time. They were the "heralds of God declaring judgement and the future hope of salvation, and crying against the inequities of the people and their leaders" (Kromminga 1960, 414).

1 What is meant using the term "principalities and powers" is defined mostly by the work of Charles L. Campbell (2002) where he draws from previous work of Walter Wink and William Stringfellow on the topic of principalities and powers. Campbell identifies those as material and spiritual institutions of that influence and utilize power over the people.

2 The heavy focus of the OT prophets was the religious decadence of the time and idolatrous practices of the people of Israel yet many of the prophets strongly addressed social injustices of the time and spoke on behalf of the poor and the marginalized. The champions of the social justice call among the prophets were Amos, Micah, Jeremiah, Ezekiel and Isaiah. 


\section{Powers and Principalities}

In similar fashion, drawing on the work of John Steinbeck, Charles L. Campbell $(2002,10)$ identifies the powers and principalities not as "simply spiritual beings in the heavens but super human creatures with a spirit and life of their own beyond human control, that shape human lives." The definition for Campbell is influenced by Steinbeck's $(1999,31-32)$ story of the "bank" written in the time of the Great Depression, where the bank is a clear representation of such an institutional power that holds sway over human destiny and often drives people to the edge of hopelessness. Campbell $(2002,24)$ identifies the characteristics of these powers and calls for "holy" confrontation claiming that ethics in preaching must not only touch the moral struggles of individual lives but must take a strong stand of resistance to the powers and principalities that are working out of rebellion against God. Therefore "prophetic preaching" that this article will seek to explore and ultimately find use of in Croatian context is a form of ethical preaching that not only speaks to the needs and struggles of individual Christian lives but a preaching that empowers a Christian community of faith to act as a prophetic entity in a rebellious world where institutional and spiritual powers exhort dominion and corrupt and negatively affect social justice ${ }^{3}$, integrity of life and various liberties.

Within the Croatian evangelical context, the term "prophetic preaching" would still by most be viewed as type of preaching most likely connected to prophesying as a manifestation of the Holy Spirit rather than an ethical form of preaching that engages the "powers and principalities." And the latter, traditionally yet clumsily interpreted from Ephesians 6:12, would also be widely viewed as exclusively spiritual opponents to the Christians. Still a fair degree of evangelical Christians in Croatia is more likely to claim that the role of the church is simply to "preach the Gospel" and not get involved with the "matters of the world" such as politics, social-justice, and matters that are relevant to the public and the poor and the marginalised. Yet, I feel that the need for such preaching is more than emphasised by the social circumstances.

Speaking out of the North American evangelical context, Marvin A. McMickle calls for a bolder type of preaching, one that is not solely focused within itself, but one that reaches the issues of the wider community outside the church fellowship. For McMickle (2006, 3), it is an "active pursuit of justice and righteousness for every member of society." Like McMickle, a lot of voices coming from the North-American evangelical context highlight the complacency that the church is complicit in regarding the problems of the wider society often claiming

3 "Preaching social justice moves from the exposure and indictment of violations to the presentation of God's vision for healthy, whole, and peaceful life in community" (Resner 2008, 135.) 
that the majority of mainline, privileged churches live in complete seclusion from the suffering world that surrounds them and are, because of it, inevitably slowly dying (cf. Jacobsen 2009, 13). Much like in the story of the merciful Samaritan in Luke 10, the church is often viewed as the religious people of the time embodied in the story by the priest and the Levite, turning a blind eye to the suffering of the world, ever inwardly focused on its religious practices and rituals.

The question that prophetic preaching raises is, can the Church, being the bearer of missio Dei, really afford to be engulfed in the "bystander effect" 4 and simply say "oh well someone else will come along and raise the voice for social justice, against racial and many other forms of discrimination, poverty, corruption, modern-day slavery and many other forms of injustice?" These different forms of suffering are what can be attributed to the work and efforts of the rebelled principalities and powers in our world and the prophetic role of the Church is to nurture a community of faith in taking a serious stand of resistance towards the institutions of power and extend the protection and merciful hand of God to the suffering world. Instead, what is often seen from the Church is a very conforming and complacent worldview that is sometimes too afraid to address these painful issues in society, often for a fear of losing footing in the social podium of influences and benefits, and often for a lack of critical judgement toward political agendas. J. Phillip Wogaman $(1998,4)$ interestingly highlights this turning of blind eye in the "German church during the Nazi regime, ${ }^{5}$ the Cuban church during the rise of the Marxist order and the Russian Orthodox church during the time of bolshevism." According to its prophetic character, the church should be speaking out during the darkest hours of humanity and being the herald of God's righteousness.

\section{The Consent on Prophetic Preaching}

There is no unanimous resolution of the term "prophetic preaching" among homileticians, but this section I will try to find common ground in different approaches to the subject and provide certain features that prophetic preaching as a homiletical practice could possess. The before mentioned McMickle (2006, 11-12) agrees with Walter Brueggemann on the role of prophetic preaching being a tool

4 According to the Oxford Dictionary of Psychology the "bystander effect" is a reluctance by the bystanders to intervene in cases of emergency and distress (Colman 2008, 107).

5 A situation similar to the relationship of the Catholic Church in Croatia and their support to the nationalism of the Ustasha movement in the period from 1941.-1945. This topic is expanded in the article by Irina Ognyanova. 2009. Religion and Church in the Ustasha Ideology 1941-1945. Croatica Christiana Periodica. 33/64. 157-90. 
to challenge what he calls a "royal consciousness" ${ }^{3}$ and mapping for the people an alternative and hopeful future where God's sovereign rule can affect the social occasions and relieve the suffering inflicted by powers disconnected from God. Yet, McMickle adds that the voice of the champions of social justice among the prophets of the Israel days were not solitary as there were others of the time that did not take upon the cause of the disenfranchised, but sided with the dominant culture enjoying the many privileges it offered to approving and assimilated voices.

The starting point for prophetic preaching is usually the assessment of the situation in society and the harmful influences and suffering realities. However, it is good to be reminded that the end agenda is not to nihilistically paint the present but rather to instil hope for the future. Most homileticians would agree that one of the strong purposes of all preaching is to draw out hope in the lives of God's people. Yet, when it comes to prophetic preaching, this seems even more emphasised. God's redemptive element of prophetic preaching comes to light when faced with what is often a grim assessment of the situation. The need for a view of a brighter future, hope and the realisation of the promises of God is an important feature of prophetic preaching (cf. Tisdale 2010, 4-9).

Another very important feature of prophetic preaching is its intended audience. The message of prophetic preaching is, contrary to what has become all too common in North-American churches, not directed to the needs of individuals but to the needs and often sufferings of the larger community. Prophetic preaching is likely to speak of and into lives that some church communities would find completely alien to their lifestyle and religious worldview. So the goal of prophetic preaching is not so much in the direct sense the edification, nurturing of discipleship, and teaching directed towards spiritual growth of individual believers. Rather it is a call to awareness for the community of believers, hope for the marginalised, and a voicing of resistance to the principalities and powers in institutions of oppressive influence. In that sense it is directed toward wider community.

Prophetic preaching is also visionary preaching. Not in the sense of foretelling the future as the name "prophetic" might suggest, but in the sense of producing and revealing a vision of alternative reality where the principalities and powers that oppress people come under submission to God through the action and mission of God's people. Vision is that which strengthens and raises those

6 According to Brueggemann $(2001,37)$ this "royal consciousness" is the dominant culture of the time during the ministries of the Israel prophets representing the royal, religious power focused on the preservation of the empire unscrupulously trampling on the marginalized and disempowered. 
very people from their warm armchairs of complacency and comfort into boldness and audacity for the kingdom of God. Still, as the cry of Martin Luther King Jr. moved masses with a strong message and the vision of a dream about a country of brotherhood, equality, freedom, and justice, the majority of white churches of the time remained apathetic and indifferent (cf. Gushee 1998, 10).

Prophetic preaching is rooted and sustained in the Scriptures, primarily by the message of the Old Testament prophets and the ministry of Jesus in the New Testament. The calling of the Old Testament prophets was to discern the circumstances the people of Israel were facing at the time of their ministry and to ask the right questions calling into account the practices and attitudes of the people. Their prophetic zeal comes from the strong sense of obligation toward the message received from God. The Old Testament prophetic literature holds therefore theological and biblical keys for unlocking the tools for prophetic messages today as the themes of corruption and bribery, dishonesty, tyranny and oppression, discrimination are more than present today. The prophets exhorted the people to "get right" with God and fellow human beings. Likewise the message and ministry of Jesus is focused on the destitute and underprivileged, sick and rejected, despised and isolated. "His prophetic identity is known when he silences oppression and when he liberates the oppressed" (Turner 2008, 101-102).

A connection can be made between narrative preaching, liberation theology, and prophetic preaching. In itself, prophetic preaching is not necessarily located in the expository or narrative homiletical camp, as it is primarily defined by its content rather than the way the message is conveyed. Yet, something can be stated about the way inductive approach ${ }^{7}$ and the use of stories to communicate the meaning, correlates to the reception of the prophetic message. The AfroAmerican liberation theology and its preaching during the civil rights movement made the OT Biblical narratives come to life as the multitude of listeners vividly re-lived the fight of Moses and God's people against oppression and slavery, and the adventures of the prophets fighting the ruling establishment of the day. ${ }^{8}$ Also what could be an argument for the narrative character of prophetic preaching is the fact that the way the realities of social injustice and oppression, and the work of the principalities and powers often find their way into the awareness of the average member of a mainline church, is if the preacher conveys that real-

7 Inductive preaching moves from experience toward the general truth as opposed to deductive preaching. (cf. Craddock 1983, 55).

8 McClure $(2007,11)$ states that "In the African American tradition, prophetic preaching identifies the biblical narrative as the listener's own story, a story that moves from suffering and lament to liberation and hope. The black tradition of social prophecy also links prophetic preaching to a practical theology of enlistment, pastoral care, and community organization for social action." 
ity through life-stories. Therefore real-life stories combined with related Biblical narratives become powerful and important preaching tools for creating a shock moment of awareness, and evoking the question "could this really be happening among us?" among the congregation.

\section{Prophetic Preaching in Action}

In this section of the article I will present two examples of sermons in a manner of prophetic preaching from a Baptist context, and analyze them from the perspective of cultural background, biblical and theological themes, and language used. The first sermon will be that of Karl B. Johnson, the general secretary of the Baptist Union of Jamaica commemorating the emancipation of Jamaica. Johnson addresses the accountability in governing the freedom that the nation has received, and drives this argument through the biblical parable of the prodigal son. His sermon audience is wider than that of a local church, even a denomination. Johnson addresses the country of Jamaica as a whole and anthropomorphically likens it to the prodigal son that receives the freedom from his father and assumes responsibility in managing his new-found life. Johnson $(2014,128-36)$ portrays Jamaica as the prodigal son in three common points, as one who has "lost his identity, squandered his legacy and abandoned his morality." The sermon is a good example of employing New Testament parables as narratives to drive prophetic preaching even though the sermon itself is not narrative but rather deductive.

The key biblical theme for Johnson $(2014,130)$ is the prodigal son's inability to govern the freedom he was awarded, and thus there are lessons to be interconnected with the chronology of post-emancipation Jamaica. His language style is "assertive and evocative" with references to Jamaican cultural phrases and language. ${ }^{9}$ Johnson appeals to the Jamaican people admiring the strength, robustness and resilience they have shown facing the oppression and turmoil in the past. These are also the qualities that he seeks to call to light when calling on the people to confront together the influences he identifies as the negative factors in the present. These are what we could identify as the "principalities and powers" that Johnson's sermons call us to resist. He identifies "dominant imperialistic powers of today" that shape the new generations of Jamaicans who are slowly losing their distinct identity which Johnson holds in high value. He identifies poor stewardship of the country's natural resources, its culture and its people which is a clear

9 Johnson $(2014,135)$ uses Jamaican dialect phrases and sayings such as "no weh nuh better than yaad" meaning "There is nowhere better than home." 
challenge to the "governing authority". Furthermore, he identifies and calls out the "gambling industry" which he sees as a clear threat to the moral values and principles of the country.

Johnson finishes the sermon with good news reminding everyone that true freedom is experienced in God when a change of direction occurs. Johnson's sermon of the "prodigal country" corroborates the features of prophetic preaching as he directs his message to the wider community, gives evocative vision and hope for the future, names and confronts principalities and powers, and uses biblical narrative to place the hearers in the sandals of the prodigal son.

The second example sermon comes from a different context and it is that of Solomon Ademola Isholah, former general secretary of the Nigerian Baptist Convention, titled "The Purpose of a Favored Life." Isholah addresses the political leaders of Nigeria in a biblical lesson on the purpose of a favored life, which he identifies as a life of the ones in political and governing authority. Isholah's claim is based on the text in Romans 13:1-7 and states that being given the responsibility of governance is a sign of God's favor and therefore comes with a higher calling and purpose. Going through the text, Isholah $(2014,37)$ draws lessons for the governing bodies of Nigeria calling them in six points to "be God's servants, to add value to people's lives, to maintain righteousness when dealing with evil, to carry a clear conscience, to use taxes for the common good and to be diligent and committed." The targeted audience of this message are the political leaders of Nigeria, but because of the nature of their role, the repercussions of the message affect the wider society.

Isholah challenges the figures of authority and calls for reconciliation with God and a renewed fight for the well-being of the people of Nigeria and against corruption, judicial favoritism, unlawful gain and profligacy of political leaders. There is a sense of boldness to his message as it is clear from the context that it was delivered in the presence of many political leaders of the country, so the message was a direct confrontation. Isholah $(2014,33)$ sides with the people of Nigeria calling for "good roads, drinking water, uninterrupted and stable electricity, good and adequately equipped hospitals, environment for economic growth and job opportunities for young people." Throughout the sermon, he uses biblical themes and short narratives of Daniel and Joseph which he designates as godly leaders and good stewards all the while exegetically going through Romans 13 and Paul's teaching on submitting to governing authorities. His language is strong, bold and prophetic and does not shy away from utilizing exclamations such as "enough must be enough" in the face of governing authorities. Isholah's sermon of the "favored leaders" resonates with prophetic preaching as the message is directed to authorities with influence over the wider community, names and confronts the rebellious misuse of power and authority, and uses biblical 
characters that are good examples of stewardship and social justice in connection to the Nigerian situation.

Some comparison notes can be drawn from these two sermons. It is interesting that the setting of both these sermons is a commemorative occasion ${ }^{10}$ which can perhaps provide a bolder momentum for articulating a prophetic message and also provide an audience of figures of authority, thus making sure the message is delivered to the ones who are ultimately meant to hear it as a stand. Also, it is evident that there is a moment in both sermons when the preacher appeals to the values and virtues of the people or the culture and the many advantages and blessings of the country itself. The principalities and powers are not ambiguously present in subtext but are clearly named and addressed in both sermons and both sermons use biblical narratives and characters as analogy to the identification of their present situation.

\section{Croatian context}

The question that has slowly played out in the back of my mind from the moment prophetic preaching became a topic of interest is: how can this be applied in my context? Similar to the American context that McMickle (2006, 30-31) is writing about, the Church in Croatia limits its fight for justice primarily on two issues, that of abortion and human sexuality. What is furthermore interesting is that the Evangelical community in Croatia, ${ }^{11}$ although usually very critical and skeptical of the Roman-Catholic Church, will have no problem joining forces in the fight for these particular issues. Unfortunately, other issues of social justice are rarely mentioned from the pulpits or issued in media statements by religious leaders. Much could be said about the political engagement, position of power and political bias of the dominant religious expression we are witnessing in Croatia. However, to be fair, we are witnessing similar examples of misuse of religious political power in dominantly evangelical countries as well. An interesting question for further exploration would be how Campbell's definition of principalities and powers applies to church institutions that are not designated protest voices but are rather a strong and powerful majority, sometimes wielding political influence. This then raises the possibility of them demonstrating some of the same features

10 For Johnson it is commemorating Jamaica's independence and for Isholah it is the birthday of a high political figure, the executive governor of Oyo State.

11 What is understood as "Evangelical community in Croatia" are all those churches that could be put under a common denominator, those churches theologians like McClendon and Parushev call "baptistic" with a small "b," baptist, pentecostal, Church of Christ and other free evangelical church communities. 
attributed to the principalities and powers. ${ }^{12}$

The question that remains for the Croatian evangelical community is that of a potential path for voicing a prophetic message that not only deals with issues of same-sex marriage and abortion but recognizing the powers and principalities in Croatia and raising a voice in issues such as high unemployment and poverty, migration of the young and highly educated workforce, corruption in the highest instances of political power and arising nationalism and xenophobia. The platform for this type of preaching does not come easy as the Evangelical community in Croatia is very small in comparison to the dominant religion. But, unlike Isholah's sermon directly pointed to the governing officials, Croatian evangelicals can voice a strong and bold vision to be preached in their communities and empower their congregations to social action raising awareness about these important social themes and being the people of God's mission. There is much that can be achieved by the grace of God but the Church in Croatia must hear the distinct prophetic call from God "whom shall I send?" and boldly answer "here we are!"

\section{Conclusion}

Prophetic preaching calls for strong and bold challenging of principalities and powers at work in our world and taking the side of the marginalized and disenfranchised in the conflict with these powers. Continuing the ministry of Jesus that was prophetic in both word and in liberating action, the church in its different cultures and contexts must find new ways to get the prophetic message across and take a stand for those that cannot stand for themselves. Many NGO's and different social organizations across Europe and the world have claimed the prophetic mantle as the church often chose to remain silent, yet our responsibility for this world cannot escape us. The church must take up the cause not only in issues of morality that trigger us in a special way, but with special attention to suffering that surrounds us in our local contexts, find new ways of reaching the wider society with the message of liberation, hope, and forgiveness.

\section{Bibliography}

Brueggemann, Walter. 2001. The Prophetic Imagination. Minneapolis: Fortress Press.

Campbell, Charles L. 2002. The Word before the Powers - an Ethic of Preaching. 
London: Westminster John Knox Press.

Colman, Andrew M. 2008. A Dictionary of Psychology. Oxford: Oxford University Press.

Craddock, Fred B. 1983. As One without Authority. Nashville TN: Abingdon Press.

Gushee, David P., and Robert H. Long. 1998. A Bolder Pulpit: Reclaiming the Moral Dimension of Preaching. Valley Forge: Judson Press.

Isholah, Solomon Ademola. 2014. The Purpose of a Favoured Life. In Baptist Preaching: A Global Anthology, edited by Joel C. Gregory, 29-37. Waco: Baylor University Press.

Jacobsen, David Schnasa. 2009. Schola Prophetarum: Prophetic Preaching Toward a Public, Prophetic Church. Homiletic, 34/1, 12-21.

Johnson, Karl B. 2014. Commemorating Jamaica’s Emancipation. In Baptist Preaching: A Global Anthology, edited by Joel C. Gregory, 128-36. Waco: Baylor University Press.

Kromminga, Carl G. 1960. Preaching. In Baker's Dictionary of Theology: Preach, Preaching, edited by Everett Falconer Harrison, G. W. Bromiley and Carl F. H. Henry, $414-15$. London: Pickering \& Inglis Ltd.

McClure, John S. 2007. Preaching Words: 144 Key Terms in Homiletics. Louisville: Kentucky: Westminster John Knox Press.

McMickle, Marvin A. 2006. Where have all the Prophets Gone? - Reclaiming Prophetic Preaching in America. Cleveland: The Pilgrim Press.

Resner, André. 2008. Social Justice. In The New Interpreters Handbook of Preaching, edited by Paul Scott Wilson, 135-37. Nashville: Abingdon Press.

Steinbeck, John. 1999. The Grapes of Wrath, Penguin Great Books of the Twentieth Century. New York: Penguin Books.

Tisdale, Leonora Tubbs. 2010. Prophetic Preaching: A Pastoral Approach. Louisville: Westminster John Knox Press.

Turner, Mary Donovan. 2008. Prophetic Preaching. In The New Interpreter's Handbook of Preaching, edited by Paul Scott Wilson, 101-02. Nashville: Abingdon Press.

Wogaman, Phillip J. 1998. Speaking the Truth in Love: Prophetic Preaching to a Broken World. Louisville: Westminster John Knox Press. 


\section{Filip Grujić}

\section{Prema kontekstualnom proročkom propovijedanju}

\section{Sažetak}

Ovaj je tekst rasprava o proročkom propovijedanju definiranom u okviru homiletike. Iznosi teološki i praktičan prikaz ovoga stila propovijedanja, dok aktivno traži način da ga kontekstualizira u hrvatskim okolnostima. Tekst nudi nekoliko odgovora na pitanje: Što je proročko propovijedanje te kako i zašto se ono provodi? Ujedno služi kao izazov i početak rasprave o proročkom propovijedanju u hrvatskom kontekstu. Dok Crkva u okruženju, koje je sve više poslijekršćansko, traži načine komuniciranja Evanđelja sa širom društvenom zajednicom, svjesna da polako gubi svoj povlašteni položaj, čini se važnim ponovno pronaći taj proročki glas koji ljude i institucije moći poziva da se pomire s Bogom i da na ljudska bića počnu gledati kao na svoje bližnje, a ne kao na sredstva. 